\title{
UPS (UNINTERRUPTIBLE POWER SUPPLY) 1000 WATT BERBASIS PANEL SURYA
}

\author{
Try Edo Saputra ${ }^{1)}$, Yosi Apriani ${ }^{2 *}$, Muhammad Hurairah ${ }^{3)}$ \\ email Co Author : yosi_apriani@um-palembang.ac.id $*^{2}$
}

\begin{abstract}
Dosen Tetap Prodi Teknik Elektro Fakultas Teknik Universitas Muhammadiyah Palembang ${ }^{2}$ Alumni Prodi Teknik Elektro Universitas Muhammadiyah Palembang ${ }^{1 \& 3}$
\end{abstract}

\begin{abstract}
ABSTRAK
Seiring berkembangnya teknologi, kebutuhan manusia makin hari makin meningkat contohnya kebutuhan penggunaan energi listrik banyak menggunakan peralatan-peralatan elektronik yang canggih dan praktis. Meningkatnya konsumsi energi listrik maka dari pihak PLN tidak mampu memenuhi pasokan listrik. Hal tersebut mengakibatkan pihak PLN melakukan tindakan pemadaman listrik secara bergilir karena kapasitas beban sudah melebihi kapasitas yang sudah ditentukan. Mengantisipasi pemadaman listrik bergilir dibutuhkanlah pemasok daya cadangan untuk menjaga pasokan energi listrik menjadi stabil dengan menggunakan sistem UPS (Uninterruptible Power Supply). UPS adalah peralatan listrik yang dapat memberikan daya cadangan saat daya utama terputus/padam dan berfungsi untuk melindungi/memproteksi peralatan elektronik dari berbagai kerusakan. Tujuan dari penelitian ini untuk membandingkan sumber dari PLN dan sumber dari baterai yang di-backup oleh inverter. Maka metode penelitian ini didapatkan hasil tegangan sumber PLN sebesar $201 \mathrm{~V}$ dan hasil tegangan yang masuk ke baterai sebesar $12.55 \mathrm{~V}$.
\end{abstract}

Kata Kunci : UPS, Baterai, PLN, Panel Surya, inverter

\section{PENDAHULUAN}

Dari tahun ke tahun teknologi selalu berkembang maka kebutuhan manusia makin hari makin meningkat contohnya pada kebutuhan penggunaan energi listrik. Kebutuhan manusia banyak menggunakan peralatan-peralatan elektronik yang canggih dan praktis. Meningkatnya konsumsi energi listrik maka dari pihak PLN sebagai penyedia listrik tidak bisa memenuhi kapasitas beban yang terlalu besar. Hal tersebut mengakibatkan pihak PLN melakukan tindakan pemadaman listrik secara bergilir karena kapasitas beban sudah melebihi kapasitas yang sudah ditentukan. (Bawotong et al., 2015)

Pemadaman listrik secara bergilir akan memberikan lonjakan daya listrik yang tiba-tiba sehingga menyebabkan kegagalan perangkat keras internal seperti kerusakan pada software atau hardware sehingga mengakibatkan peralatan komunikasi atau monitoring tidak bisa berfungsi dengan semestinya, yang artinya akan menyebabkan kerugian yang cukup besar, baik kerugian karena tidak dapat beroperasi maupun kerugian kerusakan peralatan (Najoan et al., 2017). Dari pernyataan tersebut, diperlukan sebuah alat yang dapat menyuplai daya listrik ke peralatan elektronik ketika sumber utama dari PLN padam secara tiba-tiba.

Cara mengantisipasi terjadinya pemadaman listrik bergilir dibutuhkanlah pemasok daya cadangan untuk menjaga pasokan energi listrik menjadi stabil dengan menggunakan sistem UPS (Uninterruptible Power Supply). UPS adalah peralatan listrik yang dapat memberikan daya cadangan saat daya utama terputus/padam. UPS juga termasuk sebuah sistem yang berdiri sendiri tanpa sistem suplay dari tenaga listrik PLN dan berfungsi untuk melindungi/mem proteksi peralatan elektronik dari berbagai kerusakan.

Daya cadangan UPS bersumber dari DC yang disimpan dalam baterai. Sistem UPS dapat dihubungkan dengan beban-beban seperti beban lampu, komputer, kipas angin dan lain sebagainya. 
Ketika sumber utama energi listrik pada, beban-beban tersebut tetap mendapatkan daya listrik dari UPS. Selama terputusnya sumber PLN maka UPS akan menyuplai kebutuhan daya beban. (Payung et al., 2020).

UPS bekerja diantara peralatan elektronik dan colokan listrik. Dari colokan listrik akan mengubah dari arus AC menjadi DC lalu dialirkan ke baterai yang berada di UPS. Sehingga arus DC dari baterai akan diubah menjadi arus $\mathrm{AC}$ oleh inverter. Baterai akan bekerja untuk menyimpan cadangan daya dan akan dipakai ketika energi utama listrik terputus/padam.

Pada penelitian ini sistem penelitian dirancang untuk menjaga suplai beban tanpa terputus sehingga dapat menstabilkan energi terhadap peralatan elektronik seperti kipas angin dan lampu ketika saluran beban utama dari tegangan listrik PLN terputus.

Alat ini merupakan suatu sistem yang didesain agar komponen-komponen pada kipas angin tidak mengakibatkan kegagalan perangkat keras internal yang dapat merusak komponen elektronik tersebut. Yang mana diharapkan dapat memberikan tegangan regulasi yang baik dan mampu memberikan arus yang cukup untuk beban, maka jika terjadinya pemadaman listrik secara tiba-tiba, peralatan elektronik tersebut masih bisa digunakan untuk beberapa jam kedepan dan dapat membuat komponen-komponen dari elekletronik ini seperti software maupun hardware nya tidak mudah rusak.

\section{TINJAUAN PUSTAKA}

\subsection{Baterai}

Baterai atau yang sering disebut dengan Aki adalah sebuah alat yang dapat menyimpan energi listrik dalam bentuk energi kimia. Baterai ini biasanya digunakan sebagai penyimpanan energi listrik saat proses terjadinya pengisian suatu beban dan juga berguna sebagai sumber daya untuk seluruh sistem kelistrikan pada peralatan listrik, Aki terdiri dari beberapa sel, dalam standar internasional setiap satu sel memiliki tegangan sebesar 2 volt, sehingga aki 12 volt memiliki 6 sel dan aki 24 volt memiliki 12 sel. (Warjono \& Suryono, 2015).

\subsection{Inverter}

Mengubah arus searah (DC) menjadi arus bolak balik (AC) merupakan fungsi dari inverter. Selain itu juga inverter berfungsi untuk menurunkan tegangan dari 12 VDC menjadi 220 VAC yang setara dengan tegangan pada PLN. Tegangan AC menghasilkan bentuk gelombang persegi dan perlunya filter pada pemakaian tertentu untuk menghasilkan bentuk gelombang sinusoida. Ada 2 cara dalam pengaturan besar tegangan. Pertama, dengan mengatur tegangan input DC dari luar tetapi lebar waktu penyaklaran tetap. Kedua, mengatur lebar waktu penyaklaran dengan tegangan input DC tetap (Haryanto, 2011).

\subsection{Panel Surya}

Menurut (Yusiana \& Matalata, 2017) Matahari dapat memberikan manfaat untuk energi listrik yang berasal dari efek photovoltaic, efek photovoltaic ini terdiri dari susunan semi conductors untuk menghasilkan energi listrik. Namun sayangnya panel surya memiliki kendala seperti memiliki daya yang kecil dan biaya pembelian yang relatif mahal. Untuk memaksimalkan kinerja dari system panel surya maka diperlukan sebuah alat tambahan yang dapat membuat panel surya menghasilkan daya listrik yang maksimal.

\section{METODOLOGI}

Perencanaan ini dimulai dari mendesain dan merancang UPS dengan menggunakan dua sumber yaitu PLN dan baterai. UPS akan bekerja secara otomatis saat kondisi PLN padam, dimana inverter akan menstabilkan kipas agin dan lampu agar peralatan eletronik tersebut tidak langsung mati saat PLN padam. Fungsi lain dari UPS ini juga dapat melakukan pengecasan pada handphone yang dikendalikan oleh charger. Sistem kerja akan dijelaskan dalam bentuk diagram flowchart alat dan alur kerja pada Gambar dibawah ini. 


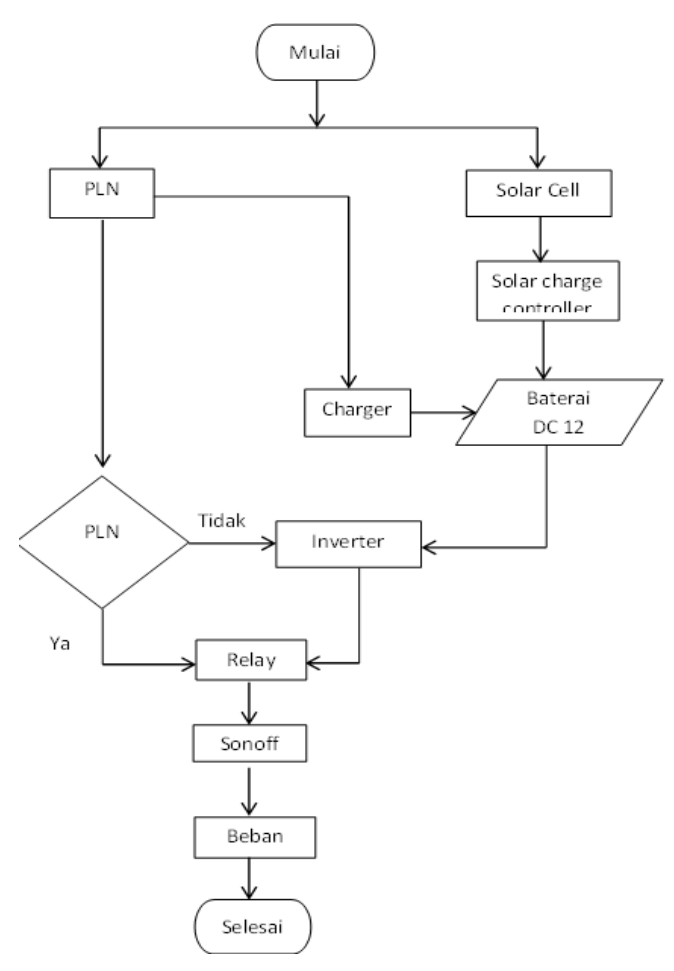

Gambar 1. Alir Keseluruhan Kerja Alat

1. Tahapan Penelitian dan Pembuatan Alat

a. Tahapan pembuatan alat ini dimulai dari tahap merancang.

b. Rancang bangun ini mempunyai dua alur suplai yaitu PLN dan panel surya. PLN merupakan sumber utama dari UPS. PLN akan masuk langsung ke relay dan beban jika PLN terputus suplai akan pindah ke inverter.

c. Sedangkan panel surya merupakan sumber cadangan dari UPS saat listrik padam. Panel surya juga merupakan sumber pengecasan utama baterai yang mengubah energi panas dari cahaya matahari menjadi energi listrik.

d. Dari solar cell baterai perlu pengaturan untuk pengecasannya yakni memerlukan SCC (solar charge controller), guna mengatur arus dan tegangan masuknya.

e. Setelah dari SCC masuknya arus untuk mengecas baterai, dimana baterainya berupa arus DC yang sudah terisi daya dari panel sehingga baterai tersebut mengalir langsung ke inverter tetapi baterai tersebut diatur terlebih dahulu di SCC sehingga inverter dapat mengubah arus baterai DC menjadi arus AC.

f. Sebelum inverter mengalir ke beban, terlebih dahulu mengkoneksikan ke baterai DC yang biasanya memiliki keluaran sebeasar 12 VDC - 24 VDC maka inverter juga dapat mengecilkan arus AC menjadi $220 \mathrm{~V}$ walaupun tidak ada jala PLN sama sekali tetapi inverter ini dapat menyuplai beban dengan baik.

g. Setelah inverter mengeluarkan beban berupa arus AC maka arus tersebut akan mengalir ke Sonoff, dimana sonoff ini berfungsi untuk meng- ON/OFF-kan beban secara otomatis. Fungsi lain dari sonoff ini dapat mendeteksi keluaran arus dan tegangan secara otomatis, hasil keluaran tersebut dapat dilihat di aplikasi e-welink. 


\section{Hasil dan Pembahasan}

\subsection{Data Pengisian Baterai}

Pengisian beterai ini harus diuji dengan tegangan baterai maksimum sebesar $11 \mathrm{~V}$ tidak boleh dibawah $11 \mathrm{~V}$ karena akan mempercepat kerusakan pada baterai. Pada pengujian ini peneliti mengukur tegangan keluaran dan arus AC dari PLN kemudian mengukur tegangan keluaran dan arus DC dari baterai dengan waktu per10 menit.

Tabel 1 Hasil Keseluruhan Pengujian Pengisian Baterai

\begin{tabular}{|c|c|c|c|c|c|}
\hline $\begin{array}{c}\text { Waktu } \\
\text { (WIB) }\end{array}$ & $\begin{array}{c}\text { Tegangan } \\
\text { AC PLN } \\
\text { (V) }\end{array}$ & $\begin{array}{c}\text { Arus } \\
\text { AC PLN } \\
\text { (A) }\end{array}$ & $\begin{array}{c}\text { Tegangan } \\
\text { Pengecasan } \\
\text { DC (V) }\end{array}$ & $\begin{array}{c}\text { Arus } \\
\text { Pengecasan } \\
\text { DC (A) }\end{array}$ & $\begin{array}{c}\text { Tegangan } \\
\text { Baterai (V) }\end{array}$ \\
\hline 12.30 & 201 & 0.72 & 12.55 & 5.83 & 11.7 \\
\hline 12.40 & 200 & 0.74 & 12.93 & 5.85 & 12.2 \\
\hline 12.50 & 197 & 0.77 & 13.21 & 5.85 & 12.5 \\
\hline 13.00 & 195 & 0.76 & 13.49 & 5.59 & 12.7 \\
\hline 13.10 & 194 & 0.63 & 13.69 & 4.58 & 12.9 \\
\hline 13.20 & 197 & 0.47 & 13.98 & 3.44 & 13.1 \\
\hline 13.30 & 195 & 0.33 & 14.26 & 2.33 & 13.2 \\
\hline 13.40 & 198 & 0.12 & 13.43 & 0.70 & 13.33 \\
\hline
\end{tabular}

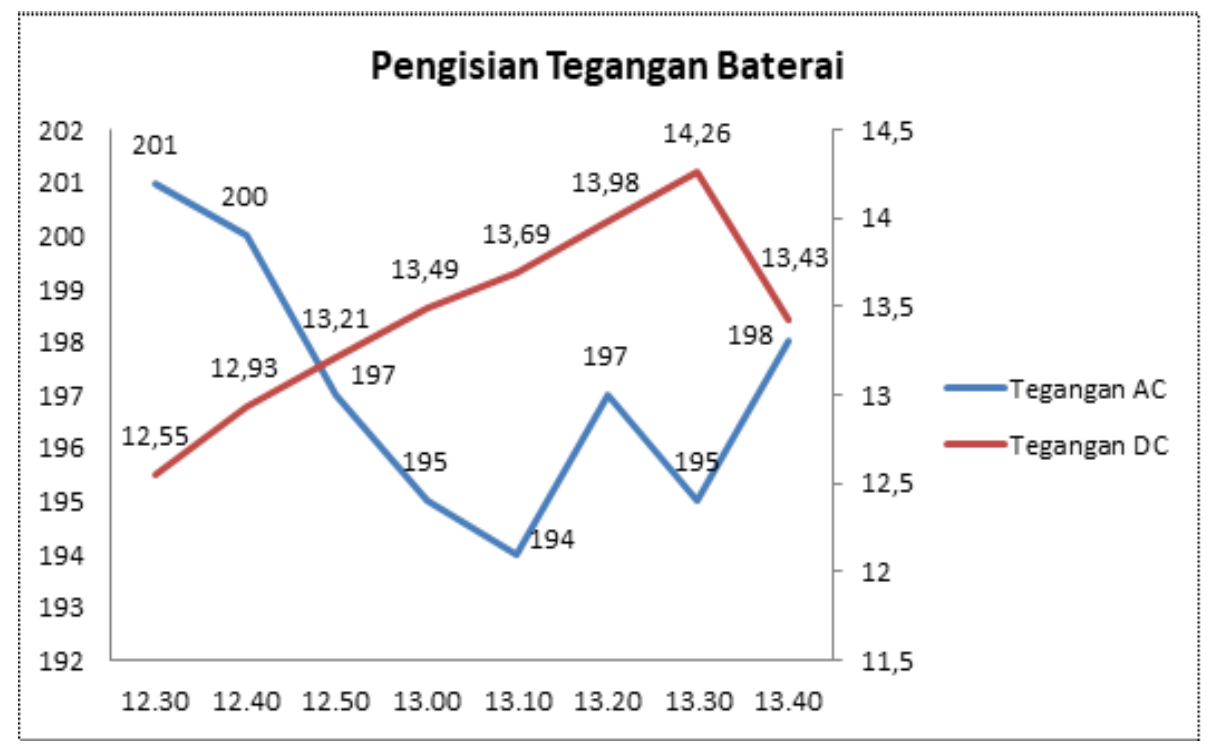

Gambar 2 Grafik Tegangan AC dan DC saat Pengisian 


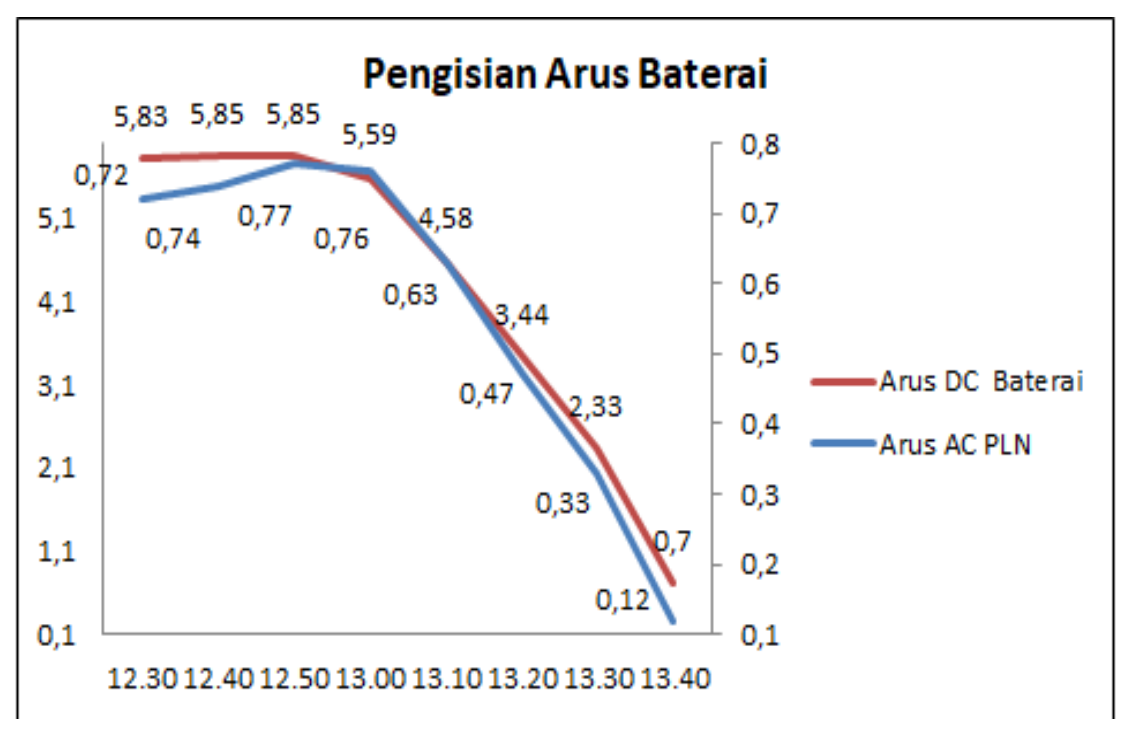

Gambar 3 Grafik Arus AC dan DC saat Pengisian

Dari data pengujian diatas maka dapat terlihat pengisian baterai keseluruhan memakan waktu selama 1 jam 10 menit, pada arus dan tegangan PLN AC disimpulkan bahwa semakin baterai terisi per10 menit maka arus dan tegangan tersebut semakin menurun. Ada beberapa faktor yang membuat arus dan tegangan makin menurun yaitu bisa karena UPS jauh dari trafo distribusi PLN, bisa juga karena padatnya penduduk dilingkungan pengujian yang mengakibatkan banyaknya pemakaian listrik sehingga kualitas tegangan keluaran dari PLN menjadi buruk dan membuat pengisian baterai menjadi lambat. Sedangkan pada arus dan tegangan DC dari keluaran baterai dapat disimpulkan bahwa semakin baterai terisi per10 menit maka arus dan tegangan DC dari baterai memperlihatkan hasil kualitas yang bagus.

\section{Data Pengosongan Beban}

Pengosongan beban ini menggunakan 2 percobaan yaitu kipas angin 45 Watt sebagai beban induktif dan lampu pijar 40 Watt sebagai beban resistif.

Tabel 2 Hasil Keseluruhan Pengujian Pengosongan Beban Induktif (Kipas Angin 45 Watt)

\begin{tabular}{|c|c|c|}
\hline Waktu (WIB) & Tegangan Baterai (V) & Arus Baterai (A) \\
\hline 11.44 & 12.76 & 5.63 \\
\hline 12.04 & 12.39 & 5.59 \\
\hline 12.14 & 12.19 & 5.52 \\
\hline 12.24 & 12.00 & 5.38 \\
\hline 12.34 & 11.77 & 5.26 \\
\hline 12.44 & 11.47 & 5.15 \\
\hline 12.54 & 10.96 & 4.97 \\
\hline
\end{tabular}




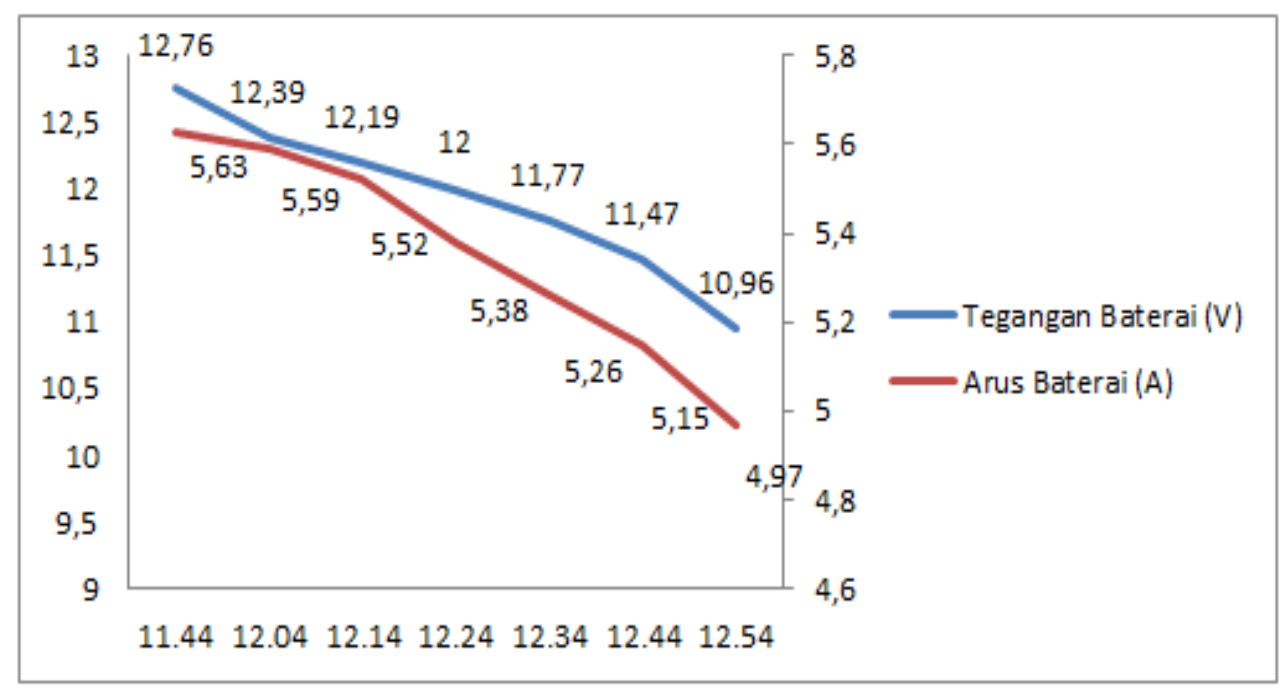

Gambar 4 Grafik Pengosongan Beban Induktif (Kipas Angin 45 Watt)

Dari data pengujian diatas terlihat bahwa percobaan ini dicoba dari baterai penuh sampai low dan hanya bisa dilakukan sampai 7 percobaan saja dalam waktu per10 menit. Pengukuran percobaan 1 sampai 7 didapatkan nilai yang makin menurun tiap percobaan, hal tersebut terjadi karena beban sudah terpakai dan akan mengalami penurunan. Pengosongan beban pada kipas angin ini termasuk normal dalam pemakaian baterainya dan menghemat energi. Dalam pengosongan beban induktif dengan kipas angin 45 Watt dilakukan pada pukul 11.44 WIB sampai dengan 12.54 WIB sehingga memakan waktu selama 1 jam 10 menit.

Tabel 3 Hasil Keseluruhan Pengujian Pengosongan Beban Resistif (LampuPijar40Watt)

\begin{tabular}{|c|c|c|}
\hline Waktu (WIB) & Tegangan Baterai (V) & Arus Baterai (A) \\
\hline 14.30 & 12.61 & 7.09 \\
\hline 14.40 & 12.30 & 6.87 \\
\hline 14.50 & 12.05 & 6.75 \\
\hline 15.00 & 11.77 & 6.64 \\
\hline 15.10 & 11.36 & 6.44 \\
\hline 15.14 & 11.13 & 6.37 \\
\hline
\end{tabular}


Dari data pengujian diatas terlihat bahwa pengosongan beban pada lampu pijar ini termasuk tidak hemat energi, per Watt pemakaiannya rendah karena pada pengujian hanya bisa dilakukan sebanyak 6 percobaan saja. Dalam pengosongan beban resistif dengan lampu pijar 40 Watt dilakukan pada pukul 14.30 WIB sampai dengan 15.44 WIB sehingga memakan waktu selama 54 menit, pada percobaan 5 ke percobaan 6 hanya memakan waktu sebanyak 6 menit saja karena pada inverter memberikan sinyal kepada UPS kalau baterai yang digunakan sudah lemah dan mengakibatkannya inverter berbunyi sebagai petanda bahwa baterai harus segera melakukan pengisian

\section{PENUTUP}

1. Keuntungan UPS ini dapat menstabilkan dan memberikan cadangan listrik sementara saat listrik padam dengan bantuan panel surya. Karena panel surya bisa mengkonversi energi dari matahari menjadi energi listrik, sehingga dapat menghemat energi listrik saat siang hari. Selain itu inverter sangat berperan penting pada rancang bangun ini karena bisa mengubah tegangan awal baterai 12 $\mathrm{V}$ menjadi $220 \mathrm{~V}$ yang berfungsi menyuplai beban (maksimal beban yang disuplai sebesar 45 Watt).

2. Hasil pengisian sumber PLN didapatkan nilai tegangan $<220 \mathrm{~V}$ mengakibatkan nilai tegangan tidak stabil, dikarenakan padatnya penduduk, banyaknya pemakaian listrik di lingkungan penduduk dan jauhnya lokasi pengujian dari trafo distribuksi. Dari ketiga hal tersebut bisa mengakibatkan tegangan dari PLN kurang baik sehingga didapatkan nilai tegangan yang tidak stabil.

3. Pada pengosongan beban peneliti membatasi kapasitas beban \pm 45 watt karena kapasitas baterai yang dipakai pada rancang bangun ini hanya sebesar 9 Ah gunanya untuk menjaga kestabilan dan kesehatan baterai pada UPS.

\section{DAFTAR PUSTAKA}

[1] Bawotong, V. T., Mamahit, D. J., Eng, M., \& Sompie, S. R. U. A. (2015). Rancang Bangun Uninterruptible Power Supply Menggunakan Tampilan LCD Berbasis Mikrokontroler. E-Journal Teknik Elektro Dan Komputer, 1, 1-7.

[2] Azizi, K. (2017). Portable Power Solar Energy Salah satu permasalahan dalam era globalilsasi ini yaitu pencemaran lingkungan dan kebakaran hutan yang terjadi karena faktor alam dan faktor manusia, Kecerobohan perkemahan dihutan atau gunung. Dalam teknologi ini dikembangk. Portable Power Solar Energy, 1, 84-92.

[3] Najoan, V. K., Wuwung, J. O., Manembu, P. L., \& Elektro-ft, J. T. (2017). Rancang Bangun Multiple-UPS Switching System Berdasarkan Variasi Beban Menggunakan Microcontroller. 6(3), 133-140.

[4] Payung, Y. R., Purwanto, E., \& Murdianto, F. D. (2020). Rancang Bangun Buck-Boost Converter Pada Sistem Charging Baterai dengan Sumber Solar Cell Menggunakan Kontrol PI pada Uninterruptible Power Supply ( UPS ) Offline untuk Aplikasi Beban Rumah Tangga. 1(2), $10-15$.

[5] Warjono, S., \& Suryono. (2015). Rancang Bangun Uninterruptible Power Supply (Ups) 1300 Va. Orbith, 11(3), 209-213.

[6] Haryanto, H. (2011). Pembuatan Modul Inverter sebagai Kendali Kecepatan Putaran Motor Induksi Pendahuluan Metodologi Penelitian. Rekayasa.

[7] Yusiana, V., \& Matalata, H. (2017). Transistor 1(Transistor 2N3055 DAN MJ2955)Jurnal Civronlit Universitas Batanghari Vol.2 No.1 Tahun 2017. 2(1), 18-22 